\title{
Omega-3 fatty acids, phenolic compounds and antioxidant characteristics of chia oil supplemented margarine
}

\author{
Muhammad Nadeem ${ }^{1 *}$, Muhammad Imran², Imran Taj ${ }^{1}$, Muhammad Ajmal' ${ }^{1}$ and Muhammad Junaid ${ }^{1}$
}

\begin{abstract}
Background: Chia (Salvia hispanica L.) is known as power house of omega fatty acids which has great health benefits. It contains up to $78 \%$ linolenic acid $(\omega-3)$ and $18 \%$ linoleic acid $(\omega-6)$, which could be a great source of omega-3 fatty acids for functional foods. Therefore, in this study, margarines were prepared with supplementation of different concentrations of chia oil to enhance omega-3 fatty acids, antioxidant characteristics and oxidative stability of the product.

Methods: Margarines were formulated from non-hydrogenated palm oil, palm kernel and butter. Margarines were supplemented with 5, 10, 15 and 20\% chia oil $\left(T_{1}, T_{2}, T_{3}\right.$ and $\left.T_{4}\right)$, respectively. Margarine without any addition of chia oil was kept as control. Margarine samples were stored at $5{ }^{\circ} \mathrm{C}$ for a period of 90 days. Physico-chemical (fat, moisture, refractive index, melting point, solid fat index, fatty acids profile, total phenolic contents, DPPH free radical scavenging activity, free fatty acids and peroxide value) and sensory characteristics were studied at the interval of 45 days.

Results: The melting point of $T_{1}, T_{2}, T_{3}$ and $T_{4}$ developed in current investigation were $34.2,33.8,33.1$ and $32.5^{\circ} \mathrm{C}$, respectively. The solid fat index of control, $T_{1}, T_{2}, T_{3}$ and $T_{4}$ were $47.21,22.71,20.33,18.12$ and 16.58\%, respectively. The a-linolenic acid contents in $T_{1}, T_{2}, T_{3}$ and $T_{4}$ were found $2.92,5.85,9.22,12.29 \%$, respectively. The concentration of eicosanoic acid in $T_{2}, T_{3}$ and $T_{4}$ was 1.82, 3.52, 6.43 and 9.81\%, respectively. The content of docosahexanoic acid in $T_{2}$, $\mathrm{T}_{3}$ and $\mathrm{T}_{4}$ was present $1.26,2.64,3.49$ and $5.19 \%$, respectively. The omega-3 fatty acids were not detected in the control sample. Total phenolic contents of control, $T_{1}, T_{2}, T_{3}$ and $T_{4}$ samples were $0.27,2.22,4.15,7.23$ and $11.42 \mathrm{mg} \mathrm{GAE} / \mathrm{mL}$, respectively. DPPH free radical scavenging activity for control, $T_{1}, T_{2}, T_{3}$ and $T_{4}$ was noted $65.8,5.37,17.82,24.95,45.42$ and $62.8 \%$, respectively. Chlorogenic acid, caffeic acid, quercetin, phenolic glycoside $\mathrm{k}$ and phenolic glycoside $\mathrm{Q}$ in $\mathrm{T}_{3}$ were present $0.78,0.73,1.82,4.12$ and $4.49 \mathrm{mg} / \mathrm{mL}$, respectively. After 90 days of storage period, free fatty acids and peroxide value of all the treatments were less than $0.2\left(\%\right.$ and $\left.\mathrm{MeqO}_{2} / \mathrm{kg}\right)$. Sensory characteristics of treatments were not different from the control.
\end{abstract}

Conclusion: Margarines supplemented with chia oil showed enhanced level of omega-3 fatty acids and antioxidant characteristics. These results suggest that chia oil can be used for formulation of margarine with increased level of omega-3 fatty acids and acceptable sensory characteristics.

Keywords: Margarine, Omega-3 fatty acids, Chia oil, Phenolic compounds, Sensory evaluation

\footnotetext{
* Correspondence: muhammad.nadeem@uvas.edu.pk

${ }^{1}$ Department of Dairy Technology, University of Veterinary and Animal

Sciences, Lahore, Punjab 54000, Pakistan

Full list of author information is available at the end of the article
} 


\section{Background}

Margarines are characterized on the basis of melting point and hardness [1]. Margarines and shortenings are usually formulated from partially hydrogenated fats which lead to the generation of therapeutically dangerous trans fatty acids. On the basis of scientific information, it has been concluded that trans fatty acids do not perform any beneficial biochemical function in the human body [2]. Trans fatty acids increase the harmful LDL cholesterol and reduce the beneficial HDL cholesterol. The excessive intake of trans fatty acids may lead to cardiovascular diseases, cancer and inflammation [3]. Blending of oils and fats is a straight forward method of developing margarine. It has already been established that physical, chemical characteristics and fatty acid profile of functional margarine product differs from conventional product $[4,5]$. On the other hand, with the advancement of knowledge in food nutrition, consumers have started to avoid foods which are formulated from partially hydrogenated fats. Therefore, the demand for functional foods is increasing across the globe [6].

Chia (Salvia hispanica L.) has its place from the family Labiatae and chia seeds have been the part of human nutrition for about 1500 years BC as staple food in Mexican region [7]. It produces about 35-40\% good quality edible oil and possesses the highest concentration of omega- 3 fatty acids of all the available food sources [8]. Therefore, it is regarded as powerhouse of omega-3 fatty acids. Scientific evidences have shown that omega3 fatty acids have cardiac-protective, anti-inflammatory and hypotensive effects [9]. Researchers are trying to improve the functional value of foods by adding omega- 3 fatty acids in foods. Consumption of such fortified foods decreased triglycerides level in serum [10]. Numerous efforts have been made to improve the nutritional value of margarine by supplementation with polyunsaturated fatty acids. When improving the nutritional value of margarine, it is extremely important to take into consideration its oxidative acceptability. Polyunsaturated fatty acids are susceptible to auto-oxidation which lead to the generation of characteristics oxidized flavour and toxic oxidation products during the long term storage of fats and oils [11]. During the storage, table margarine usually suffers from the defects of sandiness, surface discoloration, hardening, separation of oil phase and greasy texture [12]. Therefore, the oxidative stability of table margarine is highly important for practical application, nutritional and consumer preferences. Antioxidants are usually added to retard the oxidation in margarine as unrestricted activity of free radicals can lead to atherosclerosis, thrombosis, cancer, accelerated ageing and diabetes [13]. To avoid oxidative stresses, food should be supplemented with polyphenols and beneficial impacts of polyphenols on various biochemical functions of human body have been extensively studied [14]. Earlier investigation has disclosed that chia oil is a good source of phenolic compounds such as cholorogenic acid, caffeic acid, quercetein, phenolic glycoside- $\mathrm{K}$ and phenolic glycoside-Q [15]. Azeem et al. [16] studied the impact of chia seed extract for the stabilization of winterized cottonseed oil at ambient temperature. The chia seed extract significantly inhibited the lipid peroxidation and increased the shelf life of cottonseed oil.

Significance of this research work is to develop margarine containing omega-3 fatty acids. Many studies have been performed to improve the fatty acid composition of margarine, however little is known regarding the effect of vegetable oil on linolenic acid, docosahexanoic acid, eicosapentanoic acid, phenolic compounds and antioxidant characteristics of margarine. This study aimed to determine the effect of various concentrations of chia oil on omega- 3 fatty acids, phenolic compounds and antioxidant characteristics of table margarine on the basis of chemical and oxidative stability properties.

\section{Methods \\ Materials}

Chia seeds were purchased from market of Lahore and oil was extracted from unroasted seeds with laboratory scale expeller. Palm oil, palm kernel oil and palm olein were obtained from United Industries Ltd. Faisalabad. Cultured and unsalted butter was procured from Haleeb Foods, Phool Nagar. Reagents used in this investigation were HPLC grade and purchased from Sigma Aldrich (St. Louis MO, USA).

\section{Experimental plan}

In the present Investigation, $\mathrm{T}_{1}$ was comprised of $70 \%$ RBD palm oil, $25 \%$ non-hydrogenated palm kernel oil and $5 \%$ chia oil. $\mathrm{T}_{2}$ was comprised of $65 \%$ RBD palm oil, $25 \%$ non-hydrogenated palm kernel oil, $10 \%$ chia oil. $\mathrm{T}_{3}$ was comprised of $60 \%$ RBD palm oil, $25 \%$ nonhydrogenated palm kernel oil and $15 \%$ chia oil and $\mathrm{T}_{4}$ was comprised of 55\% RBD palm oil, 25\% nonhydrogenated palm kernel oil and 20\% chia oil. Margarine without any addition of chia oil was kept as control. Margarine samples were stored at $5{ }^{\circ} \mathrm{C}$ for a period of 90 days. Chemical and sensory characteristics were studied at the interval of 45 days. Experiment was planned in a completely randomized design and each treatment was replicated three times.

\section{Preparation of margarine}

Formulation of margarine was comprised of $82 \%$ oil phase, $1 \%$ lecithin, $0.6 \%$ salt and $16.4 \%$ aqueous phase. Ingredients were mixed in respective oil and aqueous phases. Emulsion was formulated by mixing the both phases in electrical blender (Waring blender Model 
32BL 80, Dinamic Corporation of America, New Hartford, Connecticut, USA). For the solidification of margarine, emulsion was cooled in 11 beaker, in ice bath, containing $10 \% \mathrm{NaCl}[17]$.

\section{Physical and chemical composition of margarine}

Fat, moisture, refractive index, melting point, solid fat index, free fatty acids and peroxide value in margarine samples was determined by following the standard methods $[18,19]$.

\section{Fatty acid profile of margarine}

Fatty acid methyl esters were prepared by acid transesterification technique using Methanolic $\mathrm{HCl}(15 \%)$ as transesterifying agent. Briefly, $50 \mathrm{mg}$ samples were taken in screw capped test tubes and $2 \mathrm{~mL}$ methanolic $\mathrm{HCl}$ was added. Tubes were put in a heating block at $100{ }^{\circ} \mathrm{C}$ for $60 \mathrm{~min}$ and contents of tubes were shaken after every $10 \mathrm{~min}$. After $60 \mathrm{~min}$ tubes were cooled to room temperature and $2 \mathrm{~mL} n$-hexane and $2 \mathrm{~mL}$ deionized water were added. Vortex process was performed at $2200 \mathrm{rpm}$ for exactly $2 \mathrm{~min}$ followed by the resting of $15 \mathrm{~min}$ and supernatant was dried over anhydrous sodium sulphate. Prepared methyl esters were transferred to GC vials and injected into GC-MS (79890-A Agilent, USA) fitted with fused silica capillary Column (SP 2560; $100 \mathrm{~m}$, film thickness $25 \mu \mathrm{m}$ ) and Mass Selective Detector. Helium was used as carrier gas at the flow rate of $2 \mathrm{~mL} / \mathrm{min}$. Fatty acids were identified and quantified by FAME 37 internal standards (Sigma Aldrich, UK) [20].

\section{Antioxidant characteristics of margarine supplemented with chia oil \\ Total phenolic contents}

Total phenolic contents were determined according to the method prescribed by Velioglu et al. [21]. Two hundred and fifty $\mathrm{mg}$ samples were mixed with $1.5 \mathrm{~mL}$ of $10 \%$ solution of Folin-Ciocalteu. After $5 \mathrm{~min}, 1.5 \mathrm{~mL}$ of sodium carbonate $(6 \%)$ solution were added. Tubes were incubated in the dark for $60 \mathrm{~min}$. Absorbance was read at $760 \mathrm{~nm}$ in visible region of spectra on a double bean spectrophotometer (Shimadzu, Japan) against a blank and results were reported as $\mathrm{mg}$ gallic acid equivalent per $100 \mathrm{~g}$ (mg GAE/g).

\section{Scavenger effect on DPPH free radicals}

$\mathrm{DPPH}$ free radical scavenging activity was determined by following the method of Brand-Williams et al. [22]. $60 \mathrm{mg}$ sample was mixed with $2.44 \mathrm{~mL}$ of DPPH solution and samples were incubated at room temperature for $60 \mathrm{~min}$. Absorbance was recorded at $515 \mathrm{~nm}$ on a double beam spectrophotometer (Shimadzu, Japan).
HPLC characterization of phenolic compounds in margarine Chlorogenic acid, caffeic acid, quercetin, phenolic glycoside$\mathrm{K}$ and phenolic glycoside-Q were determined on HPLC fitted with quaternary pump and Diode Array Detector. Light sources were deuterium and tungsten lamps on 190$195 \mathrm{~nm}$ through reverse phase elution while column specifications were $250 \times 4.6 \mathrm{~mm}, 5 \mu \mathrm{m}$ (LC-18 column) and $250 \mathrm{~mm}$ and 4.6 i.d. (Symmetry C18 column). Mobile phase was comprised of $6 \%$ acetic acid prepared in $2 \mathrm{mM}$ sodium acetate and acetonitrile. $10 \mu \mathrm{L}$ was injected, flow rate was maintained at $1 \mathrm{~mL} / \mathrm{min}$ and total run time was $75 \mathrm{~min}$. Internal standards of chlorogenic acid, caffeic acid, quercetin, phenolic glycoside- $\mathrm{K}$ and phenolic glycoside- $\mathrm{Q}$ were prepared in ethanol [23].

\section{Oxidative stability during storage}

Margarines were stored at $5{ }^{\circ} \mathrm{C}$ for 90 days and were sampled at 0,45 and 90 days. Peroxide value and free fatty acids value was determined according to the standard methods of American Oil Chemists Society [19]. Thriobarbituric acid value was determined at $0,60,120$ and 180 days of storage period [19] while Induction period was determined at $120{ }^{\circ} \mathrm{C}$ with $20 \mathrm{l}$ of oxygen by Professional Rancimat 892 (Metrohm Corporation, Switzerland).

\section{Sensory evaluation}

Sensory evaluation of margarines supplemented with chia oil was performed by a panel of ten trained judges. Sensory evaluation was performed in well illuminated laboratory at $20 \pm 2{ }^{\circ} \mathrm{C}$. Samples of margarines were coded with three digit random number and all the servings were fully randomized. Margarine samples were evaluated for colour, flavour and texture on 9 point scale [24].

\section{Statistical analysis}

The average of the three samples was reported as the measured value with standard deviation. Significant difference among the treatments was determined by Tuckey's Test. The sample analysis for storage stability and consumer acceptability was carried out in triplicate and the significant differences were calculated among means at a probability level of 5\% [25].

\section{Results and discussion}

Chemical composition, physical and chemical characteristics of margarine supplemented with chia oil

The quality control analysis of substrate oils have been given in Table 1. Fat, moisture and salt content of control and experimental margarines were not different from each other $(p>0.05)$. In our preliminary investigations, chemical composition of control was determined. The ratios of fat, moisture and salt content were 
Table 1 Quality control analysis of substrate oils

\begin{tabular}{llll}
\hline Parameter & Palm Oil & Palm Kernel Oil & Chia Oil \\
\hline Free Fatty Acids\% (oleic Acid) & $0.09 \pm 0.01^{\mathrm{b}}$ & $0.10 \pm 0.02^{\mathrm{b}}$ & $0.14 \pm 0.01^{\mathrm{a}}$ \\
Saponification Value $(\mathrm{mg} \mathrm{KOH} / \mathrm{g})$ & $194 \pm 1.44^{\mathrm{b}}$ & $216 \pm 4.55^{\mathrm{a}}$ & $188 \pm 2.73^{\mathrm{b}}$ \\
Unsapnifiable Matter\% & $0.68 \pm 0.07^{\mathrm{a}}$ & $0.65 \pm 0.03^{\mathrm{a}}$ & $1.17 \pm 0.09^{\mathrm{b}}$ \\
Peroxide Value $\left(\mathrm{MeqQ}_{2} / \mathrm{kg}\right)$ & $0.18 \pm 0.02^{\mathrm{a}}$ & $0.21 \pm 0.04^{\mathrm{a}}$ & $0.22 \pm 0.05^{\mathrm{a}}$ \\
lodine Value $\mathrm{Cg} / 100 \mathrm{~g}$ (Wijs) & $53.2 \pm 1.29^{\mathrm{b}}$ & $18.7 \pm 0.59^{\mathrm{c}}$ & $195.4 \pm 1.21^{\mathrm{a}}$ \\
\hline
\end{tabular}

Values represent the mean \pm standard deviation; $n=3$

Means in a row with different superscript letters were significantly different $(p<0.05)$

adjusted according to the control, which was the reason for non-variation in compositional attributes of margarine. Chemical characteristics of control and different types of margarine are presented in Table 2. Free fatty acids of all the treatments and control were not different from each other $(p>0.05)$. Free fatty acids of RBD palm oil, palm kernel oil, butter and mechanically extracted crude oil from non-roasted chia seeds were 0.10, 0.11, 0.13 and $0.14 \%$, respectively. Lower free fatty acids content of substrate oil led to the lower fatty acids in all the treatments. Free fatty acids are produced as a result of hydrolysis of triglycerides, moisture, lipases, metal ions and temperature. These are considered as the important factors which influence the generation of free fatty acids. Studies of Zhang et al. [26] revealed that free fatty acids of margarine after 12 weeks of storage at $5{ }^{\circ} \mathrm{C}$ were less than $0.2 \%$ which is the allowable limit for free fatty acids. Supplementation of margarine with chia oil decreased the melting point of all the four treatments $(p<0.05)$. Melting point is an important parameter during the development of table margarine as it helps to determine the spreadibility of margarine after taking out from refrigerator. Melting point provides a temperature indication at which margarine ought to be smooth in the palette. Table (soft) margarine should be immediately spreadable, after taken out from the refrigerator, with no oiling out [27]. International standard range of melting point for the margarine is $28-34{ }^{\circ} \mathrm{C}$ which suggests that margarine should quickly melt in the mouth and be firm enough to tolerate the mechanical work during the spreadibility. Melting point of $\mathrm{T}_{1}, \mathrm{~T}_{2}, \mathrm{~T}_{3}$ and $\mathrm{T}_{4}$ developed in current investigation were 34.2, 33.8, 33.1 and $32.5{ }^{\circ} \mathrm{C}$, which were within the range of international standards. Solid fat index indicates the percentage of triglycerides solidified at a particular temperature. It is an important indicator of many features of foods together with appearance; spreadability and mouth feel of margarine. It also measures the degree of crystallization of fats [28]. Solid fat content is an extremely useful parameter in the formulation of margarine at $10{ }^{\circ} \mathrm{C}$. It determines the hardness of the finished product at refrigeration conditions [29]. Concentration of solid fat in margarine at $10{ }^{\circ} \mathrm{C}$ should be more than $10 \%$ to prevent oiling off. At $10{ }^{\circ} \mathrm{C}$, amount of solid fat in all the treatments was more than $10 \%$. At $20{ }^{\circ} \mathrm{C}$, solid fat index of control, $\mathrm{T}_{1}, \mathrm{~T}_{2}, \mathrm{~T}_{3}$ and $\mathrm{T}_{4}$ were 47.21, 22.71, 20.33, 18.12 and $16.58 \%$, respectively (Table 3 ). At $30{ }^{\circ} \mathrm{C}$, solid fat index of control, $\mathrm{T}_{1}, \mathrm{~T}_{2}, \mathrm{~T}_{3}$ and $\mathrm{T}_{4}$ were 16.42, 4.52, 3.18, 2.82 and $2.21 \%$, respectively. At $37{ }^{\circ} \mathrm{C}$, Solid fat content of margarine should be less than 6\% [30]. In current investigation, solid fat index of all the treatments at $37{ }^{\circ} \mathrm{C}$ at was less than $6 \%$ which shows that these

Table 2 Physical and chemical characteristics of margarine supplemented with chia oil

\begin{tabular}{llllll}
\hline Parameter & Control & $T_{1}$ & $T_{2}$ & $T_{3}$ & $T_{4}$ \\
\hline FFA \% & $0.11 \pm 0.02^{\mathrm{a}}$ & $0.11 \pm 0.02^{\mathrm{a}}$ & $0.12 \pm 0.01^{\mathrm{a}}$ & $0.11 \pm 0.02^{\mathrm{a}}$ & $0.12 \pm 0.02^{\mathrm{a}}$ \\
$\mathrm{MP}^{\circ} \mathrm{C}$ & $35.4 \pm 0.22^{\mathrm{a}}$ & $34.0 \pm 0.15^{\mathrm{b}}$ & $33.8 \pm 0.25^{\mathrm{c}}$ & $33.2 \pm 0.18^{\mathrm{d}}$ & $32.1 \pm 0.21^{\mathrm{e}}$ \\
$\mathrm{IV} \mathrm{Cg} / 100 \mathrm{~g}$ & $47.5 \pm 1.48^{\mathrm{e}}$ & $57.6 \pm 1.21^{\mathrm{d}}$ & $60.15 \pm 1.10^{\mathrm{c}}$ & $65.6 \pm 0.71^{\mathrm{b}}$ & $70.9 \pm 0.52^{\mathrm{a}}$ \\
$\mathrm{PV}\left(\mathrm{MeqO}_{2} / \mathrm{kg}\right)$ & $0.22 \pm 0.07^{\mathrm{a}}$ & $0.25 \pm 0.01^{\mathrm{a}}$ & $0.26 \pm 0.05^{\mathrm{a}}$ & $0.21 \pm 0.03^{\mathrm{a}}$ & $0.24 \pm 0.02^{\mathrm{a}}$ \\
$\mathrm{Rl} @ 40^{\circ} \mathrm{C}$ & $1.454 \pm 0.02^{\mathrm{a}}$ & $1.457 \pm 0.01^{\mathrm{a}}$ & $1.459 \pm 0.02^{\mathrm{a}}$ & $1.463 \pm 0.03^{\mathrm{a}}$ & $1.467 \pm 0.02^{\mathrm{a}}$ \\
\hline
\end{tabular}

Values represent the mean \pm standard deviation; $n=3$

Means in a row with different superscript letters were significantly different $(p<0.05)$

FFA Free Fatty Acids (Oleic Acid)

$M P$ Melting Point ${ }^{\circ} \mathrm{C}$

IV lodine Value (Wijs)

PV Peroxide Value $\left(\mathrm{MeqO}_{2} / \mathrm{Kg}\right)$

$R I$ Refractive Index at $40^{\circ} \mathrm{C}$

Control: Margarine Sample without Chia Oil

$\mathrm{T}_{1}$ : Margarine Supplemented with 5\% Chia Oil

$\mathrm{T}_{2}$ : Margarine Supplemented with $10 \%$ Chia Oil

$\mathrm{T}_{3}$ : Margarine Supplemented with 15\% Chia Oil

$\mathrm{T}_{4}$ : Margarine Supplemented with $20 \%$ Chia Oil 
Table 3 Solid fat index of margarine supplemented with chia oil

\begin{tabular}{llllll}
\hline Temperature ${ }^{\circ} \mathrm{C}$ & Control & $\mathrm{T}_{1}$ & $\mathrm{~T}_{2}$ & $\mathrm{~T}_{3}$ & $\mathrm{~T}_{4}$ \\
\hline 10 & $60.54 \pm 1.27^{\mathrm{a}}$ & $51.92 \pm 1.19^{\mathrm{b}}$ & $47.46 \pm 1.51^{\mathrm{c}}$ & $44.55 \pm 1.41^{\mathrm{d}}$ & $42.36 \pm 1.36^{\mathrm{e}}$ \\
20 & $47.21 \pm 1.23^{\mathrm{a}}$ & $22.71 \pm 1.26^{\mathrm{b}}$ & $20.33 \pm 1.78^{\mathrm{b}}$ & $18.12 \pm 1.21^{\mathrm{c}}$ & $16.58 \pm 1.11^{\mathrm{d}}$ \\
25 & $39.51 \pm 0.88^{\mathrm{a}}$ & $12.45 \pm 0.72^{\mathrm{b}}$ & $10.15 \pm 0.0 .45^{\mathrm{b}}$ & $9.70 \pm 0.63^{\mathrm{c}}$ & $7.44 \pm 1.31^{\mathrm{d}}$ \\
30 & $16.4 \pm 0.33^{\mathrm{a}}$ & $4.52 \pm 0.52^{\mathrm{b}}$ & $3.18 \pm 0.0 .39^{\mathrm{b}}$ & $2.82 \pm 0.63^{\mathrm{c}}$ & $2.19 \pm 0.28^{\mathrm{d}}$ \\
35 & $12.3 \pm 0.47^{\mathrm{a}}$ & $3.16 \pm 0.63^{\mathrm{b}}$ & $2.91 \pm 0.22^{\mathrm{c}}$ & $2.51 \pm 0.09^{\mathrm{c}}$ & $2.21 \pm 0.11^{\mathrm{d}}$ \\
37 & $4.52 \pm 0.12^{\mathrm{a}}$ & $2.36 \pm 0.10^{\mathrm{b}}$ & $2.11 \pm 0.07^{\mathrm{c}}$ & $1.84 \pm 0.13^{\mathrm{d}}$ & $1.52 \pm 0.13^{\mathrm{e}}$ \\
\hline
\end{tabular}

Values represent the mean \pm standard deviation; $n=3$

Means in a row with different superscript letters were significantly different $(p<0.05)$

Control: Margarine Sample without Chia Oil

$\mathrm{T}_{1}$ : Margarine Supplemented with $5 \%$ Chia Oil

$\mathrm{T}_{2}$ : Margarine Supplemented with $10 \%$ Chia Oil

$\mathrm{T}_{3}$ : Margarine Supplemented with 15\% Chia Oil

$\mathrm{T}_{4}$ : Margarine Supplemented with $20 \%$ Chia Oil

margarines melt quickly in mouth [17]. Formulated trans free margarine from highly saturated soybean oil and evaluation on nuclear magnetic resonance revealed only a small percentage of solid fat above $33{ }^{\circ} \mathrm{C}$. Özay et al. [31] described that solid fat content of soft tub margarine at 20 and $30{ }^{\circ} \mathrm{C}$ was 8.5 and $2.5 \%$. Iodine value determines the degree of unsaturation in oils and fats and connected with oxidative stability [32]. Supplementation of margarine with chia oil considerably increased the iodine value of all the treatments. Iodine value of $\mathrm{T}_{4}$ was 20.4 points greater than control. Oils having higher iodine values are usually susceptible to auto-oxidation. Peroxide value and refractive index of all the treatments and control were not different from each other $(p>0.05)$.

Fatty acid profile of margarine supplemented with chia oil Results of fatty acid profile of margarines supplemented with chia oil are given in Table 4 and chromatographs of GC analysis have been presented in Fig. 1. Concentrations of short-chain fatty acids in experimental samples were not different from each other, whereas, they were not detected in control. Concentration of butter in all the experimental samples was $10 \%$, which was the reason for non-significant variation in the concentration of shortchain fatty acids. Role of short-chain fatty acids in the development of typical flavour characteristics of milk and dairy products has been well established. Addition of butter in margarine improved the flavour of margarine. Margarines are usually manufactured from the blends of partially hydrogenated fats and soft oils. Partial hydrogenation of fats and oils lead to the generation of harmful trans fatty acids. Partially hydrogenated fats are the major carrier of trans fatty acids in human body. Harmful impacts of trans fatty acids on serum cholesterol level and cardiovascular diseases have been scientifically proven [3]. Concentration of trans fatty acids in control was $18.72 \%$ while experimental samples did not reveal trans fatty acids. Nadeem et al. [33] analyzed the concentration of

Table 4 Fatty acid profile of margarine supplemented with chia oil

\begin{tabular}{llllll}
\hline Fatty Acid & Control & $T_{1}$ & $T_{2}$ & $T_{3}$ & $T_{4}$ \\
\hline$C_{12: 0}$ & $4.59 \pm 0.12^{\mathrm{b}}$ & $11.25 \pm 0.51^{\mathrm{a}}$ & $10.92 \pm 0.19^{\mathrm{a}}$ & $10.63 \pm 0.28^{\mathrm{a}}$ & $11.17 \pm 0.66^{\mathrm{a}}$ \\
$\mathrm{C}_{14: 0}$ & $5.42 \pm 0.13^{\mathrm{a}}$ & $5.23 \pm 0.08^{\mathrm{a}}$ & $4.91 \pm 0.05^{\mathrm{a}}$ & $4.58 \pm 0.12^{\mathrm{a}}$ & $4.52 \pm 0.06^{\mathrm{a}}$ \\
$C_{16: 0}$ & $11.39 \pm 0.29^{\mathrm{c}}$ & $29.9 \pm 1.12^{\mathrm{a}}$ & $28.87 \pm 0.98^{\mathrm{a}}$ & $27.72 \pm 0.55^{\mathrm{b}}$ & $26.43 \pm 0.72^{\mathrm{b}}$ \\
$C_{18: 0}$ & $15.76 \pm 0.43^{\mathrm{a}}$ & $7.27 \pm 0.11^{\mathrm{b}}$ & $7.11 \pm 0.19^{\mathrm{b}}$ & $6.98 \pm 0.16^{\mathrm{b}}$ & $6.55 \pm 0.08^{\mathrm{b}}$ \\
$C_{18: 1}$ & $24.88 \pm 0.68^{\mathrm{d}}$ & $34.12 \pm 1.73^{\mathrm{a}}$ & $33.03 \pm 1.59^{\mathrm{a}}$ & $32.42 \pm 0.84^{\mathrm{b}}$ & $30.24 \pm 1.35^{\mathrm{c}}$ \\
$C_{18: 2}$ & $18.72 \pm 0.54^{\mathrm{a}}[$ Trans $]$ & $10.28 \pm 0.44^{\mathrm{b}}$ & $10.23 \pm 0.37^{\mathrm{b}}$ & $10.15 \pm 0.76^{\mathrm{b}}$ & $10.12 \pm 0.35^{\mathrm{b}}$ \\
a-Linolenic Acid & $N D$ & $2.92 \pm 0.08^{\mathrm{d}}$ & $5.85 \pm 0.34^{\mathrm{c}}$ & $9.22 \pm 0.24^{\mathrm{b}}$ & $12.29 \pm 0.51^{\mathrm{a}}$ \\
Eicosanoic Acid & $\mathrm{ND}$ & $1.82 \pm 0.05^{\mathrm{d}}$ & $3.52 \pm 0.15^{\mathrm{c}}$ & $6.43 \pm 0.27^{\mathrm{b}}$ & $9.81 \pm 0.32^{\mathrm{a}}$ \\
Docosahexanoic Acid & $\mathrm{ND}$ & $1.26 \pm 0.07^{\mathrm{d}}$ & $2.64 \pm 0.11^{\mathrm{c}}$ & $3.49 \pm 0.13^{\mathrm{b}}$ & $5.19 \pm 0.17^{\mathrm{a}}$ \\
\hline
\end{tabular}

Values represent the mean \pm standard deviation; $n=3$

Means in a row with different superscript letters were significantly different $(p<0.05)$

ND Not detected

Control: Margarine Sample without Chia Oil

$\mathrm{T}_{1}$ : Margarine Supplemented with $5 \%$ Chia Oil

$\mathrm{T}_{2}$ : Margarine Supplemented with $10 \%$ Chia Oil

$\mathrm{T}_{3}$ : Margarine Supplemented with 15\% Chia Oil

$\mathrm{T}_{4}$ : Margarine Supplemented with $20 \%$ Chia Oil 


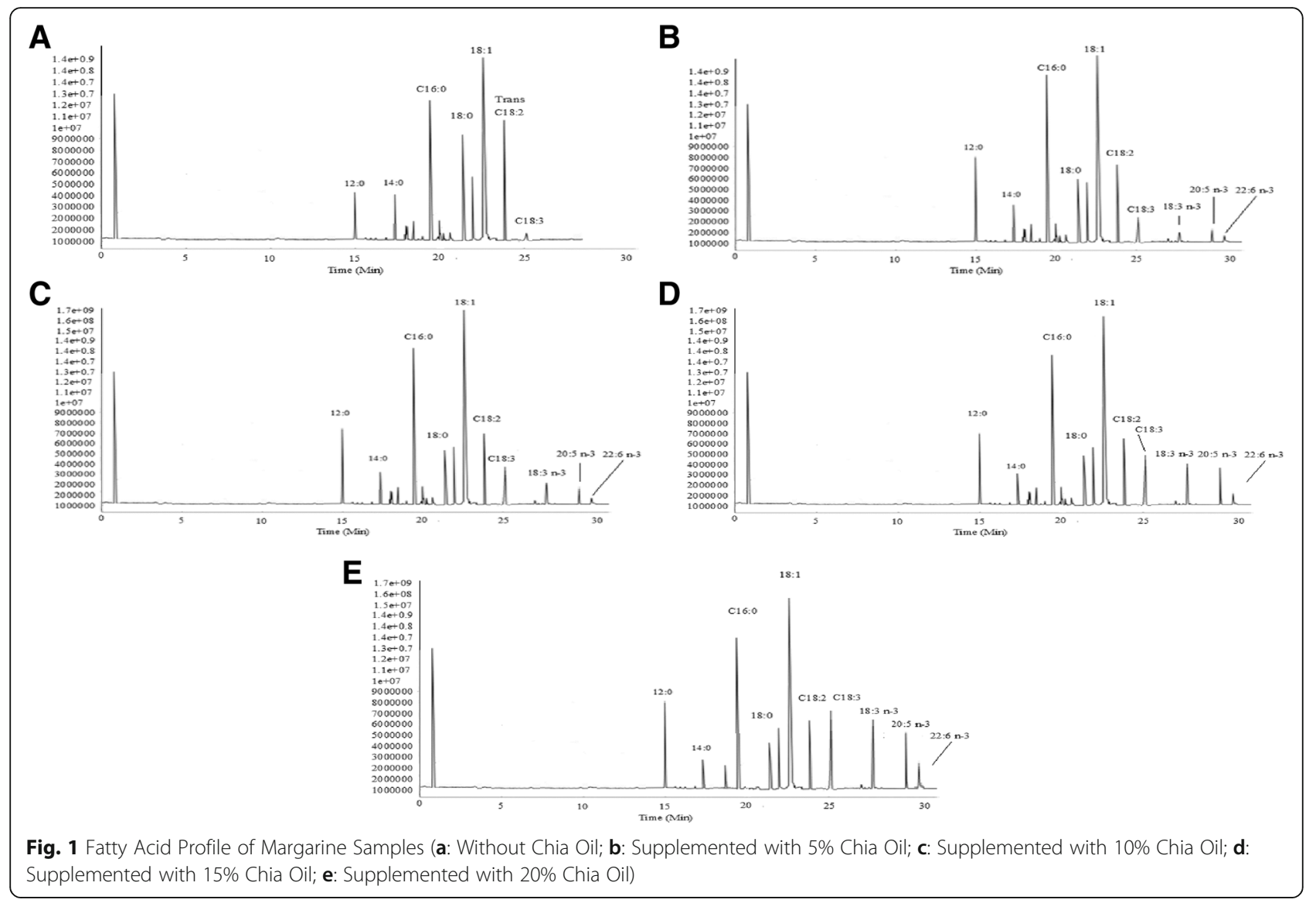

trans fatty acids in partially hydrogenated vegetable fat available in Pakistan. The concentration of trans fatty acids was greater than $20 \%$. Dollahs et al. [34] improved the concentration of oleic acid in palm stearin and palm kernel oil by Moringa oleifera oil through interesterification. The blends thus formulated were free of trans fatty acids.

Concentrations of $\alpha$-linolenic acid in $\mathrm{T}_{1}, \mathrm{~T}_{2}, \mathrm{~T}_{3}$ and $\mathrm{T}_{4}$ were $2.92,5.85,9.22,12.29 \%$, respectively. Concentration of eicosanoic acid in $\mathrm{T}_{2}, \mathrm{~T}_{3}$ and $\mathrm{T}_{4}$ were 1.82, 3.52, 6.43 and $9.81 \%$, respectively. While content of docosahexanoic acid in in $\mathrm{T}_{2}, \mathrm{~T}_{3}$ and $\mathrm{T}_{4}$ were $1.26 \%, 2.64,3.49$ and $5.19 \%$, respectively. Omega-3 fatty acids were not detected in the control. Health benefits associated with the intake of foods containing omega-3 fatty has led the researchers to formulate the functional containing omega3 fatty acids. Concentration of omega- 3 fatty acids in chia oil and its olein fraction was greater than 60 and $80 \%$ [15]. Chia seed has been declared as Novel Food by the European Union Parliament [35]. Scientific studies have evidenced that chia oil is edible with no any toxicological effects and snacks, cereal bars, yoghurt, pasta and biscuits etc. have been supplemented with chia [36]. Chia oil is regarded as the powerhouse of omega- 3 fatty acids and the cardio-protective effects of eicosapentanoic acid and docosahexanoic acid have been cited in literature [37]. Concentration of conjugated linoleic acid (Cis-9, trans-11; CLA) in $\mathrm{T}_{1}, \mathrm{~T}_{2}, \mathrm{~T}_{3}$ and $\mathrm{T}_{4}$ were 0.038 , $0.035,0.037$ and $0.034 \%$, whereas, CLA was not found in control. Anticarcinogenic, anti-diabetic, immunomodulating, antiatherogenic perspectives of CLA have been published in literature [38]. Daily dose of $3 \mathrm{~g}$ of CLA can help to prevent carcinogenesis [39]. Fatty acid composition of margarine has been improved in many studies, however, in current investigation, functional margarine was developed with higher amount of omega-3 fatty acids, CAL and no trans fatty acids.

\section{Storage effect on fatty acid profile}

Transition in fatty acid profile of fats and oils during the storage is a good indication of oxidative stability [40]. Concentrations of omega-3 \& 6 fatty acids decreased during the storage period of 90 days (Table 5). After 90 days of storage at $5{ }^{\circ} \mathrm{C}$, losses of omeg- 6 fatty acids in $\mathrm{T}_{1}, \mathrm{~T}_{2}, \mathrm{~T}_{3}$ and $\mathrm{T}_{4}$ were $0.04,0.14,0.24$ and $0.21 \%$, respectively, from the initial values. After 90 days of storage at $5{ }^{\circ} \mathrm{C}$, losses of eicosanoic acid in $\mathrm{T}_{1}, \mathrm{~T}_{2}, \mathrm{~T}_{3}$ and $\mathrm{T}_{4}$ were $0.07,0.11,0.15$ and $0.18 \%$, respectively, from the initial values. Chlorogenic acid, caffeic acid, quercetein, phenolic glycoside- $\mathrm{k}$ and phenolic glycoside- $\mathrm{Q}$ are the major phenolic compounds present in chia oil. Although 


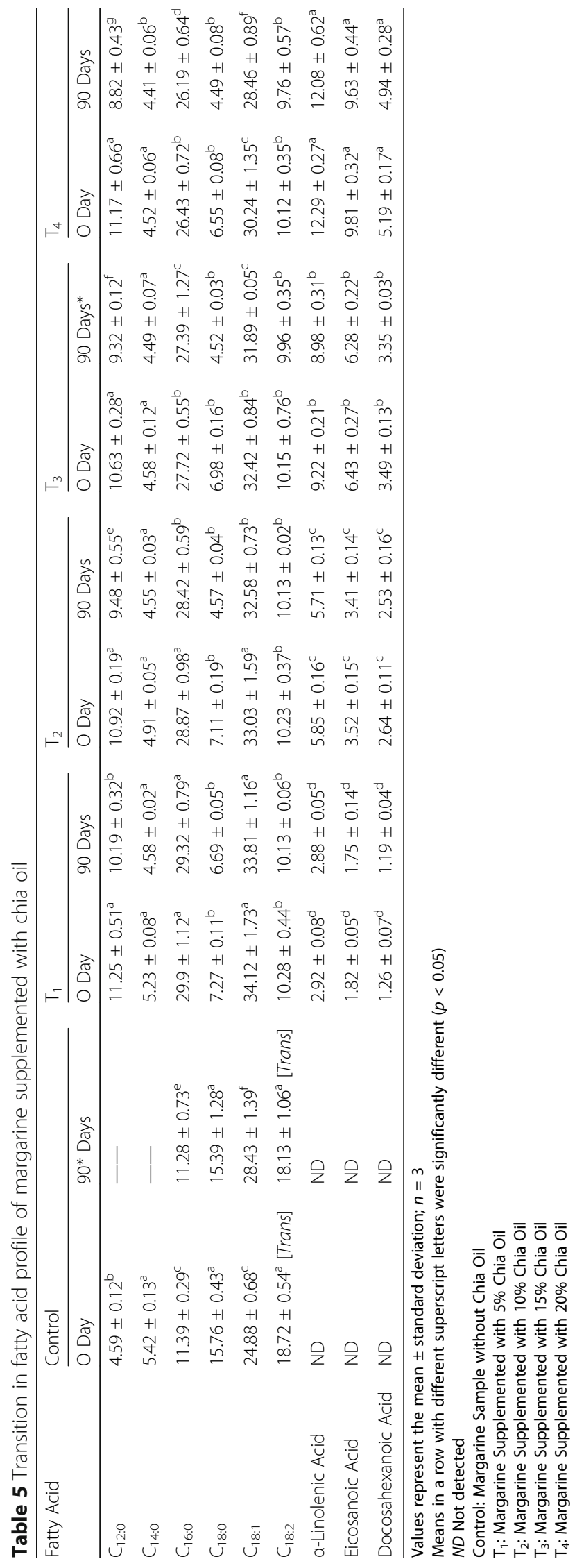


the concentration of polyunsaturated fatty acids was higher in margarines, however, phenolic compounds of chia oil strongly inhibited the lipid peroxidation in supplemented margarines. Among the food products, margarine is a typical example, which is susceptible to oxidation, because of $82 \%$ fat content [30]. Oxidation is a serious problem during the manufacturing and conservation of margarine. The most significant consequence is the development of objectionable odors which usually lead to the lower consumer acceptability [41]. For the prevention of oxidation in margarine, the processing industries normally add vitamin E. Results of current investigation have shown that phenolic substances of chia oil efficiently inhibited the oxidation of polyunsaturated fatty acids and inhibited the development of off-flavors which is also evident from the sensory score of margarine during the storage period. These results suggest that oxidative stability of margarine supplemented with chia oil was remarkable at $5{ }^{\circ} \mathrm{C}$, for a storage period of 90 days. Zhang et al. [26] studied the storage stability of margarine produced from enzymatically tailored fats and orthodox methods. Margarines stored at $5{ }^{\circ} \mathrm{C}$ for $12 \mathrm{did}$ not develop oxidative and hydrolytic rancidity. Nadeem et al. [42] monitored the changes in fatty acid profile of palm and mango kernel oil blends for a period of 90 days and the concentration of long-chain unsaturated fatty acids decreased during the storage period $(p>0.05)$. Fatty composition of blends of butter oil and mango kernel oil in ambient and accelerated oxidation (25 and $55^{\circ}$ C) was different from the fresh samples [43].

\section{Antioxidant content of margarine supplemented with chia oil}

\section{Total phenolic contents of margarine}

Total phenolic contents of control, $\mathrm{T}_{1}, \mathrm{~T}_{2}, \mathrm{~T}_{3}$ and $\mathrm{T}_{4}$ were $0.27,2.22,4.15,7.23$ and $11.42 \mathrm{mg} \mathrm{GAE} / \mathrm{mL}$, respectively. The higher phenolic contents of experimental margarines are in line with earlier investigations on chia seed. Total phenolic contents of chia seed extract and chia oil were 35 and $7.6 \mathrm{mg} \mathrm{GAE} / \mathrm{mL}$, respectively [16]. Total phenolic contents of chia oil and chia seed extract were greater than Moringa oleifera oil and sesame cake extract, 7.1 and $1.84 \%$, respectively [33, 44]. Higher total phenolic content in chia oil can be attributed to existence of chlorogenic acid, caffeic acid, quercetin, phenolic glycoside $\mathrm{P} \& \mathrm{~K}$, which were also confirmed by HPLC characterization of phenolic compounds of chia oil. Oxidative stability of margarine can be enhanced by the phenolic compounds of plant origin [45]. Antioxidant characteristics of margarine supplemented with fennel seed extract was superior to the un-supplemented margarine [46]. Supplementation of Shea butter with natural antioxidants improved the antioxidant characteristics [47].

\section{DPPH free radical scavenging activity}

Determination of DPPH free radical scavenging activity is one of the most effective and widely used methods for the assessment of antioxidant activity of antioxidants of plant origin. In current investigation, DPPH free radical scavenging activity of $100 \mathrm{ppm}$ BHT, control, $\mathrm{T}_{1}, \mathrm{~T}_{2}, \mathrm{~T}_{3}$ and $\mathrm{T}_{4}$ were $65.8,5.37,17.82,24.95$ and $62.80 \%$, respectively. $\mathrm{EC}_{50}$ for $\mathrm{T}_{4}$ was $1.25 \mathrm{mg} / \mathrm{mL}$ as compared to $\mathrm{EC}_{50}$ of BHT $1.13 \mathrm{mg} / \mathrm{mL}$. Phenolic substances of chia oil efficiently inhibited the lipid peroxidation, which is also evident form the lower peroxide value while flavour score and peroxide value were strongly correlated $\left(R^{2}=0.9982\right)$. Supplementation of margarine and butter with chokeberry polyphenols extract enhanced the antioxidant activity of fat matrix in cookies and altered the fat oxidation during the storage period of 9 weeks [48]. With a $k_{2}$ value of $37.35 \mathrm{~L} / \mathrm{moL}$, vitamin $\mathrm{E}$ is regarded as one of the most antioxidant in butter and margarine. Earlier investigation has shown that $\mathrm{k}_{2}$ value of Camu-camu (Myrciaria dubia) was $69.24 \pm 5.72 \mathrm{~L} / \mathrm{moL}$, which indicate the possibility of using phytochemicals for the preservation of fats and oils [49].

\section{HPLC characterization of phenolic compounds of margarine}

HPLC characterization of margarines supplemented with chia oil revealed that the chlorogenic acid, caffeic acid, quercetin, phenolic glycoside $\mathrm{k}$ and phenolic glycoside $\mathrm{Q}$ were the major phenolic compounds (Fig. 2). Concentrations of chlorogenic acid, caffeic acid, quercetin, phenolic glycoside $\mathrm{k}$ and phenolic glycoside $\mathrm{Q}$, in $\mathrm{T}_{1}$ were $0.33,0.22,0.42,1.07$ and $0.62 \mathrm{mg} / \mathrm{mL}$, respectively. Concentrations of chlorogenic acid, caffeic acid, quercetin, phenolic glycoside $\mathrm{k}$ and phenolic glycoside $\mathrm{Q}$, in $\mathrm{T}_{2}$ were, $0.49,0.25,0.69,1.42$ and $1.32 \mathrm{mg} / \mathrm{mL}$. Concentrations of chlorogenic acid, caffeic acid, quercetin, phenolic glycoside $\mathrm{k}$ and phenolic glycoside $\mathrm{Q}$, in $\mathrm{T}_{3}$ were $0.78,0.73,1.82,4.12$ and $4.49 \mathrm{mg} / \mathrm{mL}$. Concentrations of chlorogenic acid, caffeic acid, quercetin, phenolic glycoside $\mathrm{k}$ and phenolic glycoside $\mathrm{Q}$, in $\mathrm{T}_{4}$ were, $1.21,0.83$, 2.91, 5.23 and $5.58 \mathrm{mg} / \mathrm{mL}$. Whereas, these phenolic compounds were not detected in control samples. During orthodox processing of oils and fats, they are exposed to higher temperature while phenolic compounds are usually lost during the commercial processing of oils and fats. HPLC characterization of ethanolic chia seed extract revealed the existence of chlorogenic acid, caffeic acid, quercetin, phenolic glycoside- $\mathrm{k}$ and phenolic glycoside-Q [50]. Health benefits associated with the intake of polyphenols of plant origin have been scientifically established [51]. Earlier investigations regarding the phytochemical characterization of chia oil revealed that it possesses a wide range of phenolic compounds [52]. Chia seed is potentially a strong source of natural antioxidants and phytochemicals of chia can be 

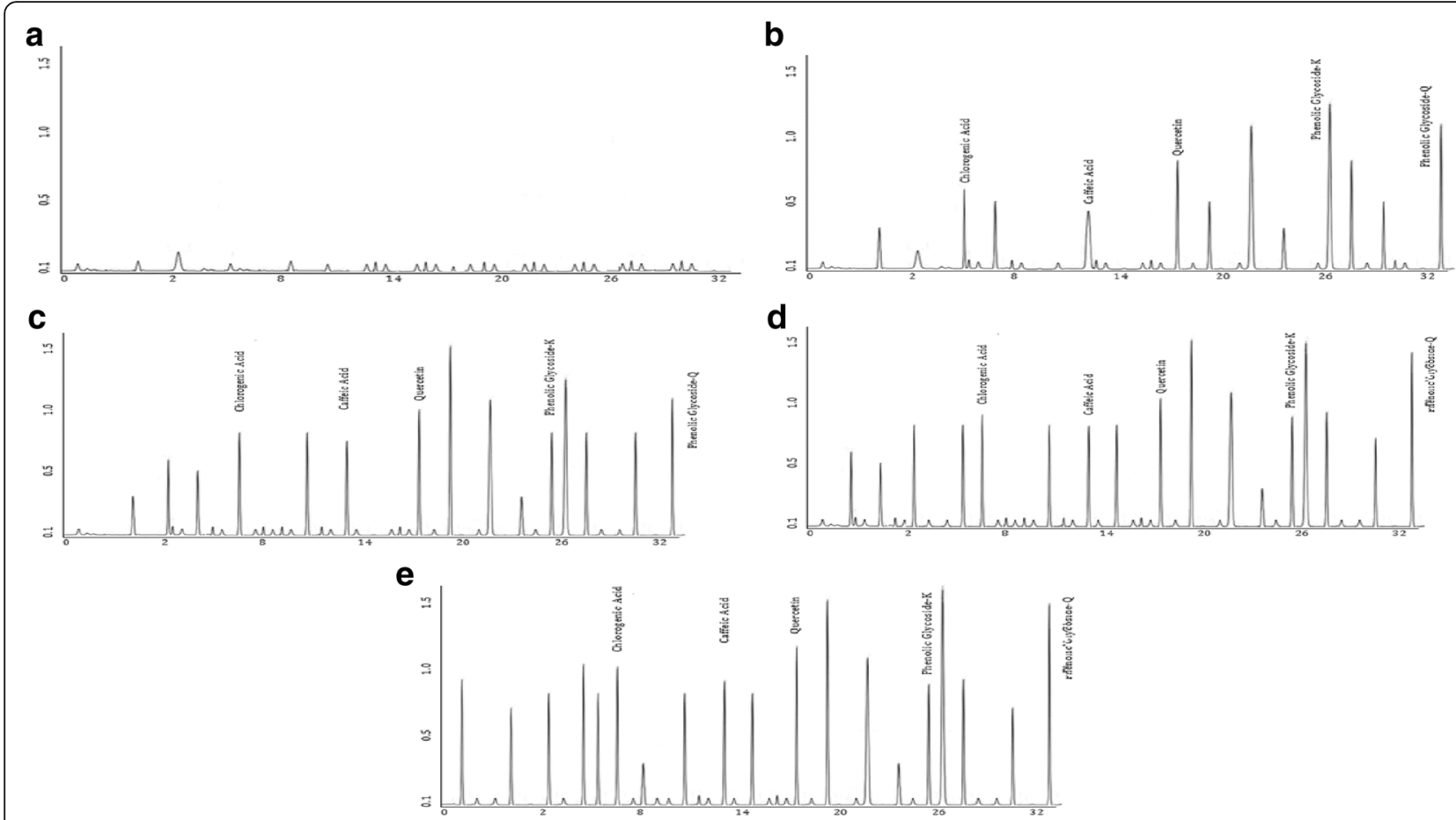

Fig. 2 Phenolic Compounds Profile of Margarine Samples (a: Without Chia Oil; b: Supplemented with 5\% Chia Oil; c: Supplemented with 10\% Chia Oil; d: Supplemented with 15\% Chia Oil; e: Supplemented with 20\% Chia Oil)

utilized for the prevention of oxidative stresses in human body and lipid peroxidation [53].

\section{Oxidative stability of margarine}

Results of oxidative stability of margarine supplemented with chia oil have been presented in Fig. 3. Free fatty acids and peroxide values were used as indicators of oxidative stability. In current investigation, free fatty acids content of crude chia oil was $0.14 \%$ (oleic acid), free fatty acids content of margarine supplemented with $12 \%$ chia oil was $0.12 \%$, which is within the allowable limits of $0.20 \%$. Lower free fatty acids of chia oil offers better adaptation for the margarine industry. Free fatty acids of all the experimental samples and control went on increasing during the storage period of 90 days. After 90 days of storage period, free fatty acids of all the experimental margarines were within the allowable limit (0.3\% European Standard EC No: ES-PDO-0105-032706.09.2011). The rise in free fatty acids of margarines during the storage period may be attributed to the lipases and metal ion contamination. Earlier investigation has shown that after 12 weeks of storage at $5{ }^{\circ} \mathrm{C}$, free fatty acids of margarine were less than $0.2 \%$ [26]. Price of crude oils is mainly based on the concentration of free fatty acids. The edible oil manufacturers treat free fatty acids as impurity. For a better shelf and flavour stability of the finished product, they must be removed/neutralized. Considerable efforts and investments are required

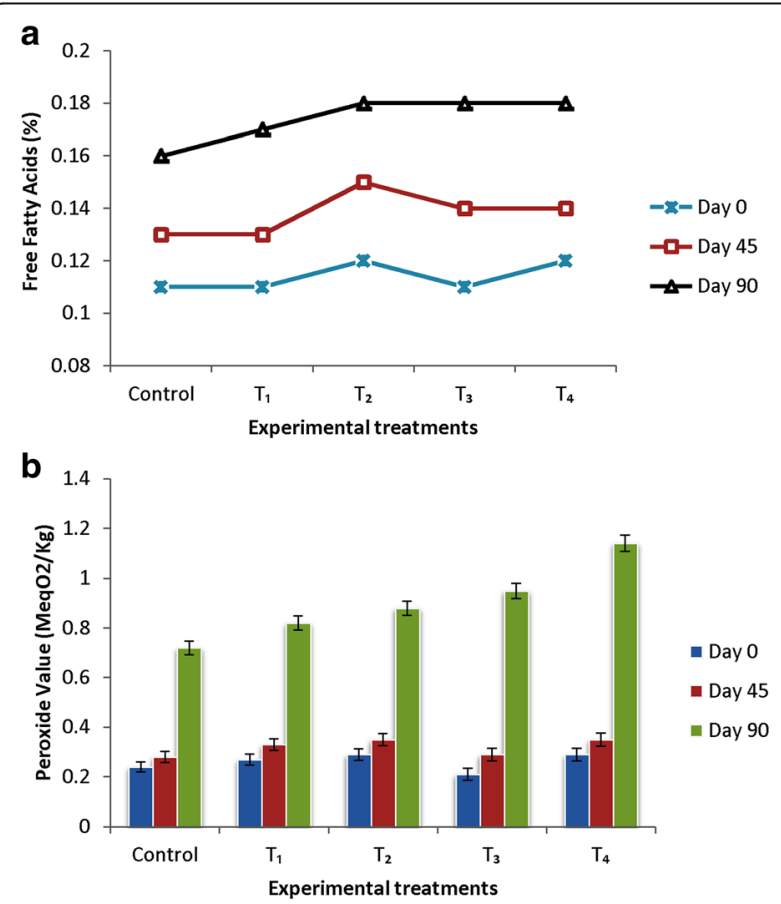

Fig. 3 Oxidative Stability of Margarine Samples (a: Free fatty acids, $\%$; b: Peroxide value, $\mathrm{MeqO}_{2} / \mathrm{Kg}$ ) 
to lower the concentration of free fatty acids in edible oils. Higher magnitude of free fatty acids can lead to accelerated breakdown of peroxides to secondary and tertiary oxidation products. Estimation of peroxide value is a good indication of oxidation status of fats and oils [54]. Peroxide value of fresh and 45 days stored margarines (stored at $5{ }^{\circ} \mathrm{C}$ ) were not different from each other and control. After 90 days of storage period, highest peroxide value was noted in $\mathrm{T}_{4}\left(1.14 \mathrm{MeqO}_{2} / \mathrm{kg}\right)$, which is much lower than the maximum limit (10MeqO2/kg; European Standard: EC No: ES-PDO-0105-0327-06.09.2011). Addition of chia oil in margarine not only improved the concentration of omega- 3 fatty acids but also altered the lipid peroxidation in supplemented margarines [55]. After 60 days of storage, TBA value of all the treatments and control were not different from freshly prepared samples (Table 6). Storage stability of margarine supplemented with $200 \mathrm{ppm}$ tocopherol and $200 \mathrm{ppm}$ rosemary extract were superior to $120 \mathrm{ppm}$ tertiary butylated hydroxyl quinone [56]. During the storage of oils and fats, lipid oxidation is one of the major causes of quality deterioration. In order to retard the oxidative breakdown or to extend the shelf life of many foods, addition of antioxidants is required [57]. Due to the perceived toxicity, absorption and accumulation in body tissues and carcinogenic properties, synthetic antioxidants have been limited in numerous countries [58]. Use of ascorbic acid, rosemary and tocopherol to retard lipid oxidation has been described [59]. Addition of natural antioxidants considerably inhibited the oxidation in margarine [60]. In current investigation, oxidative stability of margarine was enhanced through the phenolic compounds of chai oil, without any addition of antioxidants.

\section{Sensory evaluation of margarine}

Results of sensory evaluation of margarines supplemented with chia oil are presented in Fig. 4. At zero day, color, flavor and texture of all the treatments and control were not different from each other $(p>0.05)$. Storage

Table 6 Thiobarbituric acid value of chia oil supplemented margarine in short term and mid term refrigeration storage

\begin{tabular}{lllll}
\hline Treatments & 0 Day & 60 Days & 120 Days & 180 Days \\
\hline Control & $0.22 \pm 0.02^{f}$ & $0.25 \pm 0.03^{f}$ & $0.51 \pm 0.02^{\mathrm{e}}$ & $0.68 \pm 0.01^{\mathrm{d}}$ \\
$\mathrm{T}_{1}$ & $0.22 \pm 0.02^{f}$ & $0.26 \pm 0.04^{f}$ & $0.55 \pm 0.01^{\mathrm{e}}$ & $0.73 \pm 0.03^{\mathrm{d}}$ \\
$\mathrm{T}_{2}$ & $0.22 \pm 0.02^{f}$ & $0.25 \pm 0.01^{f}$ & $0.69 \pm 0.03^{\mathrm{d}}$ & $0.89 \pm 0.04^{\mathrm{b}}$ \\
$\mathrm{T}_{3}$ & $0.22 \pm 0.02^{f}$ & $0.26 \pm 0.02^{f}$ & $0.82 \pm 0.02^{\mathrm{c}}$ & $0.94 \pm 0.01^{\mathrm{b}}$ \\
$\mathrm{T}_{4}$ & $0.22 \pm 0.02^{\mathrm{f}}$ & $0.26 \pm 0.05^{\mathrm{f}}$ & $0.98 \pm 0.06^{\mathrm{b}}$ & $1.15 \pm 0.05^{\mathrm{a}}$
\end{tabular}

Values represent the mean \pm standard deviation; $n=3$

Means within the rows and columns with different superscript letters were significantly different $(p<0.05)$

Control: Margarine Sample without Chia Oil

$\mathrm{T}_{1}$ : Margarine Supplemented with $5 \%$ Chia Oil

$\mathrm{T}_{2}$ : Margarine Supplemented with $10 \%$ Chia Oil

$\mathrm{T}_{3}$ : Margarine Supplemented with $15 \%$ Chia Oil

$\mathrm{T}_{4}$ : Margarine Supplemented with $20 \%$ Chia Oil
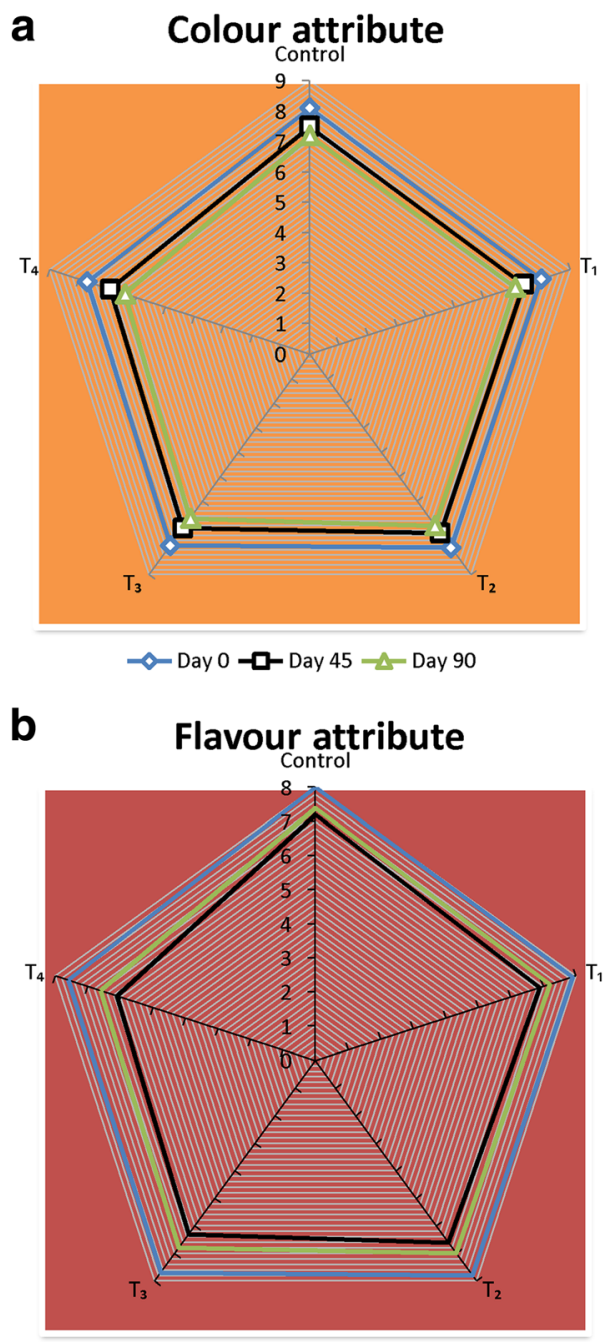

Day 0 - Day 45 Day 90

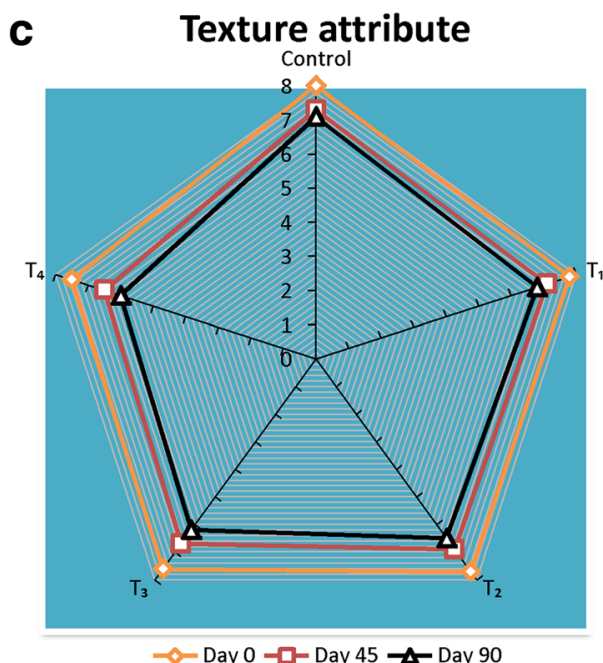

Fig. 4 Sensory Characteristics of Margarine Samples (a: Colour attribute; b: Flavour attribute; c: Texture attribute) 
period up to 45 days was non-significant for all the treatments and control. Color, flavor and texture score of 90 days stored $\mathrm{T}_{4}$ was less than other treatments and control $(p<0.05)$. After 45 days of storage period, decline in flavor score of $\mathrm{T}_{4}$ may be connected to the generation of peroxides that lead to the formation of odoriferous compounds, such as, aldehydes, ketones and alcohols. Nadeem et al. [61] recorded a strong correlation between peroxide value and flavor score. Sensory characteristics of a traditional sweet, prepared by mixing concentrated milk with margarine were better than sweet samples prepared from vanaspati. Omega-3 fatty acids of margarine were enhanced by fish oil, out of 195 analysts, only two perceived the fishy taste [62]. Lumor et al. [63] prepared trans free margarine from palm mid fraction and canola oil and sensory characteristics of trans free margarine were not different from the reference margarine.

\section{Conclusions}

Chia oil at all levels enhanced the concentration of beneficial omega-3 \& omega- 6 fatty acids antioxidant characteristics of margarine. Supplemented margarines revealed low degree of changes in fatty acid profile, yielded the lower concentration of primary and secondary oxidation products. Sensory characteristics of margarine supplemented with $15 \%$ chia oil were not different from the control. Overall, omega fatty acids and antioxidant characteristics of trans free margarine can be enhanced by chia oil supplementation.

\section{Acknowledgements}

The authors are highly obliged to the Library Department, Government College University Faisalabad (GCUF), University of Veterinary and Animal Sciences (UVAS) and IT Department, Higher Education Commission (HEC, Islamabad) for access to journals, books and valuable database.

\section{Funding}

Financial assistance for this study was provided by Higher Education Commission of Pakistan.

\section{Availability of data and materials}

The dataset supporting the conclusions of this article is included within the article.

\section{Authors' contributions}

MN conceptualized and provided the technical assistance; IT, MA and MJ performed the study and guided in the data collection; Ml helped to analyze the data and drafting the manuscript. "It's also confirmed that all the authors read and approved the final manuscript".

\section{Competing interests}

The authors declare that they have no competing interests.

\section{Consent for publication}

Not Applicable.

Ethics approval and consent to participate Not Applicable.

\section{Publisher's Note}

Springer Nature remains neutral with regard to jurisdictional claims in published maps and institutional affiliations.

\section{Author details}

'Department of Dairy Technology, University of Veterinary and Animal Sciences, Lahore, Punjab 54000, Pakistan. ${ }^{2}$ Institute of Home and Food Sciences, Faculty of Science and Technology, Government College University, Faisalabad, Punjab 38000, Pakistan.

Received: 10 February 2017 Accepted: 22 May 2017

Published online: 31 May 2017

\section{References}

1. Chrysan MM. Margarines and Spreads, Bailey's Industrial Oil and Fat Products. New York: Wiley; 2005.

2. Lokuruka MNI. Role of fatty acids of milk and dairy products in cardiovascular diseases: A review. Afr J Food Agric Nutr Dev. 2007;7:1-16.

3. Mozaffarian D, Clarke R. Quantitative effects on cardiovascular risk factors and coronary heart disease risk of replacing partially hydrogenated vegetable oils with other fats and oils. Eur J Clin Nutr. 2009;63:22-33.

4. Man D, Sher LCF, Man JMD. Composition, physical and textural characteristics of soft (tub) margarines. Ibid. 1991;68:70-3.

5. Nadeem M, Imran M, labal Z, Abbas N, Mahmud A. Enhancement of the oxidative stability of butter oil by blending with mango (Mangifera indica L.) kernel oil in ambient and accelerated oxidation. J Food Process Preserv. 2016; doi:10.1111/jppp.12957.

6. Lau TC, Chan MW, Tan HP, Kwek CL. Functional food: a growing trend among the health conscious. Asian Soc Sci. 2013;9:198-208.

7. Ayerza R, Coates W. Composition of chia (Salvia hispanica) grown in six tropical and subtropical ecosystems of South America. Trop Sci. 2004;443:131-5.

8. Ali NM, Yeap SK, Ho WY, Beh BK, Tan SW, Tan SG. The Promising Future of Chia Salvia hispanica L. J Biom Biotechnol. 2012. doi:10.1155/2012/171956.

9. Munoz LA, Cobos A, Diaz O, Aguilera JM. Chia seeds: microstructure, mucilage extraction and hydration. J Food Eng. 2016;108:216-24.

10. Liu M, Wallin R, Saldeen T. Effect of bread containing stable fish oil on plasma phospholipid fatty acids, triglycerides, HDL-cholesterol and malondialdehyde in subjects with hyperlipidemia. Nutr Res. 2001;21:1403-10.

11. Shahidi F. Baileys' Industrial Edible Oil and Fat Products. 6th ed. John Willey and Sons, Pub. Co: NY; 2005

12. Nawar WW. Lipids. In: Food Chemistry (edited by ED., N. R. A. E.) New York: Marcel Dekker Inc.1985; Pp. 139-245.

13. Kris-Etherton PM, Hecker KD, Bonanome A, Coval SM, Binkoski AE, Hilpert KF, et al. Bioactive compounds in foods: Their role in prevention of cardiovascular disease and cancer. Am J Med. 2002;113:71-88.

14. Jeong SM, Kim SY, Kim DR, Man KC, Ahn DU, Lee SC. Effect of heat treatment on the antioxidant activity of extracts from citrus peals. J Agric Food Chem. 2004:52:3389-93.

15. Ullah R, Nadeem M, Ayaz M, Imran M, Tayyab M. Fractionation of Chia Oil for Enrichment of Omega 3 and 6 Fatty Acids and Oxidative Stability of Fractions. Food Sci Biotechnol. 2016;25(1): 41-47 (2016). doi:10.1007/s10068016-0006-x.

16. Azeem W, Nadeem M and Ahmad S. Stabilization of winterized cottonseed oil with chia (Salvia hispanica I.) seed extract at ambient temperature. J Food Sci Technol. 2015. doi:10.1007/s13197-015-1823-2.

17. Kok LL, Fehr WR, Hammond EG, White PJ. Trans-free margarine from highly saturated soybean oil. J Am Oil Chem Soc. 1999;76:1175-81.

18. AOAC. Official methods of analysis. American association of analytical chemists. 2000; Inc.17th Ed. Washington, DC. USA.

19. AOCS. Official Methods and Recommended practices of the American Oil Chemists' Society. 4th ed. Champaign: AOCS; 1995.

20. Paquot C. IUPAC Standard Methods for the Analysis of Oils, Fats and Derivatives. 6th ed. Oxford: Pergamon Press; 1997.

21. Velioglu YS, Mazza G, Gao L, Omah BD. Antioxidant activity and total phenolics in selected fruits, vegetables, and drain products. J Agric Food Chem. 1998;46:4113-7.

22. Brand-Williams W, Cuvelier ME, Berset C. Use of a free radical method to evaluate antioxidant activity. Food Sci Technol. 1995;28:25-30.

23. Kim KH, Tsao R, Yang R, Cui SW. Phenolic acid profiles and antioxidant activities of wheat bran extracts and the effect of hydrolysis conditions. Food Chem. 2006;95:466-73. 
24. Larmond E. Laboratory Methods for Sensory Evaluation of Foods. Research Branch, Canada, Department of Agriculture, Ottawa Publications. 1987.

25. Steel RGD, Torrie JH, Dickey DA. Principles and Procedures of Statistics, A biometrical approach. 3rd ed. New York: Mc-Graw Hill Book Co; 1997.

26. Zhang H, Jacobsen C, Pedersenc LS, Christensenc MW, Nissena JA. Storage stability of margarines produced from enzymatically interesterified fats compared to those prepared by conventional methods-Chemical properties. Eur J Lipid Sci Technol. 2006;108:227-38. doi:10.1002/ejlt. 200500305.

27. Idris NA, de Man L, Tang TS, Chong CL. Chemical composition and physical properties of soft (tub) margarines sold in Malaysia. J Am Oil Chem Soc. 1996;73:995-1001.

28. Bongers $P$, Almeida-Rivera $C$. Dynamic modelling of the margarine production process. Computr Aided Chem Eng. 2011;29:1301-5.

29. Lai OM, Ghazali HM, Cho F, Chong CL. Physical and textural properties of an experimental table margarine prepared from lipase-catalyzed transesterified palm stearin: palm kernel olein mixture during storage. J Am Oil Chem Soc. 2000;71:173-9

30. Karleskind, A. Manual fats (vol. 1). EditionTechnology and Document (1st ed.) 1992; 65-112, 318-617.

31. Özay G, Yitchiz M, Mahidin MR, Yusof MSA, Turgadil M, Gökcen N. Formulation of trans-free acid margarines. In: Proceedings of World Conference on Oil Seed and Edible Oil Processing, Istambul. 1998;1: 143-146.

32. Erickson DR. Practical handbook of soybean processing and utilization. Champaign: AOCS press; 1995.

33. Nadeem M, Azeem MW, Rahman F. Assessment of transesterified palm olein and Moringa oleifera oil blends as vanaspati substitutes. J Food Sci Technol. 2014; doi:10.1007/s13197-014-1271-4.

34. Dollahs A, Krim SM, STT A, Kkoramina A, Mohd Ghazali H. Physio-chemical properties of moringa olifera seed oil enzymatically intersterified with palm stearin and palm kernel oil and its potential application in food. J Sci Food Agri. 2016;96(10):3321-33.

35. The Chia Company. Request for scientific evaluation of substantial equivalence application for the approval of chia seeds (Salvia hispanica L.) from The Chia Company for use in bread. Food Standards Agency London, UK. 2009.

36. Borneo R, Aguirre A. León AE Chia (Salvia hispanica L) gel can be used as egg or oil replacer in cake formulations. J Am Diet Assoc. 2010;110:946-9.

37. Manzella D, Paolisso G. Cardiac autonomic activity and Type II diabetes mellitus. Clin Sci. 2005:108:93-7.

38. Bessa RJB, Santos-Silva J, Ribeiro JMR, Portugal AV. Reticulo-rumen edible products with linoleic acid conjugated isomers. Livest Prod Sci. 2000;63: 201-11.

39. Baer RJ, Ryali J, Schingoethe DJ, Kasperson KM, Donovan DC, Hippen AR, et al. Composition and properties of milk and butter from cows fed fish oil. J Dairy Sci. 2001;84:345-53

40. Nadeem M, Situ C, Abdullah M. Effect of olein fractions of milk fat on oxidative stability of ice cream. Int J Food Prop. 2015;18:735-45. doi:10.1080/10942912.2013.814666.

41. Prior E. Usage des corps gras alimentaires dans les différents secteurs de la technologie alimentaire. In: Graille J, ed. Lipides et corps gras alimentaires. Paris: Lavoisier Tec and Doc; 2003. p. 87-147.

42. Nadeem M, Imran M, Rahman Ullah. Chemical Characteristics of Mango (Mangifera indica L.) Kernel Oil and Palm Oil Blends for Probable Use as Vanaspati. Journal of Oil Palm Research. 2016a. Accepted.

43. Nadeem M, Imran M, labal Z, Abbas1 N, Mahmud A. Enhancement of the oxidative stability of butter oil by blending with mango (Mangifera indica I.) Kernel oil in ambient and accelerated oxidation. Journal of Food Processing and Preservation. 2016b; doi:10.1111/jfpp.12957.

44. Nadeem M, Abdullah M, Khalique A, Hussain I, Mahmud A. The effect of Moringa oleifera leaf extract as antioxidant on stabilization of butter oil with modified fatty acid profile. J Agric Sci Technol. 2013;15:919-28.

45. Nawar WW. Lipids. In: Food Chemistry (edited by ED., N. R. A. E.). 1985; Pp. 139-245. New York: Marcel Dekker Inc.

46. Mahdi Y, Bassiri AR. Evaluation of the Antioxidant Potential of Fennel Seed Extract as Compared to the Synthetic Antioxidants in Margarine under Accelerated Storage Condition. J Food Biosci Technol Islamic Azad Univ Scie Res Branch. 2015;5(1):63-8.

47. Nahm HS, Juliani HR, Simon JE. Effects of selected synthetic and natural antioxidants on the oxidative stability of shea butter (Vitellaria paradoxa subsp. paradoxa). J Med Active Plants. 2012;1:69-75.
48. Bialek M, Rutkowska J, Bialek A, Adamska A. Oxidative stability of lipid fraction of cookies enriched with chokeberry polyphenols extract. Pol J Food Nutr Sci. 2016;66:77-84.

49. Rufino MSM, Ricardo E, Alves A, Fabiano AN, Fernandes B, Edy S. Brito. Free radical scavenging behavior of ten exotic tropical fruits extracts. Food Res Int. 2011;44:2072-5.

50. Tepe B, Sokmen M, Akpulat AH, Sokmen A. Screening of the antioxidant activity of six salvia species from Turkey. Food Chem. 2006;95:200-4.

51. Mohdaly AA, Smetanska Al, Rahadan MF, Sarhan MA, Mahmoud A. Antioxidant potential of sesame (sesamun indicum) cake extract in stabilization of sunflower and soybean oil. Ind Crop Prod. 2011:34:952-9.

52. Reyes-Caudillo E, Tecante A, Valdivia-Lopez MA. Dietary fibre content and antioxidant activity of phenolic compounds present in Mexican chia (Salvia hispanica L.) seeds. Food Chem. 2008;107(2):656-63.

53. Uribe JAR, Perez JIN, Kauil HC, Rubio GR, Alcocer CG. Extraction of oil from chia seeds with supercritical CO2. J Supercrit Fluids. 2011;56(2):174-8.

54. Anwar F, Hussain Al, labal S, Bhanger Ml. Enhancement of the oxidative stability of some vegetable oils by blending with Moringa oleifera oil. Food Chem. 2007;103:1181-91.

55. Chatha SAS, Hussain Al, Bajwa JR, Sherazi STH, Shaukat A. Wheat bran extracts: a potent source of natural antioxidants for the stabilization of canola oil. Grasas Aceites. 2011:62(2):190-7.

56. Azizkhani M, Zandi P. Effects of some natural antioxidant mixtures on margarine stability. Pak J Agric Sci. 2010:47(3):251-7.

57. Robbins K, Sewalt $V$. Extending freshness with rosemary extract. Inform. 2005:16(8):534-5.

58. Hras AR, Hadolin Z, Knez, Bauman D. Comparison of antioxidative and synergistic effectsof rosemary extract with alfa-tocopherol, ascorbyl palmitate, and citric acid in sunflower oil. Food Chem. 2000;71:229-33.

59. Djenane D, Sánchez-Escalante A, Beltrán JA, Pedro RP. Ability of atocopherol taurine and rosemary, in combination with vitamin C, to increase the oxidative stability of beef steaks packaged in modified atmosphere. Food Chem. 2002;76(4):407-15

60. Yue W, Xing-guo W, Ya-fei W. Effects of Four Natural Antioxidants on Oxidative Stability of Bulk Fat and Margarine J. Food Sci. 2014;35(7):17-22.

61. Nadeem M, Ullah R, Ullah A. Improvement of the Physical and oxidative stability characteristics of ice cream through intereterified Moringa oleifera oil. Pak. J. Sci. Ind. Res. Ser. B Biol Sci. 2016;59:38-43.

62. Saldeen T, Wallin R, Marklinder I. Effects of a small dose of stable fish oil substituted for margarine in bread on plasma phospholipids fatty acids and serum triglycerides. Nutr Res. 1998;18:1483-92.

63. Lumor SE, Kim BH, Akoh CC. Optimization of solid fat content and crystal properties of a trans-free structured lipid by blending with palm midfraction. J Agric Food Chem. 2008:56(19):9294-8. doi:10.1021/jf801788y.

\section{Submit your next manuscript to BioMed Central and we will help you at every step:}

- We accept pre-submission inquiries

- Our selector tool helps you to find the most relevant journal

- We provide round the clock customer support

- Convenient online submission

- Thorough peer review

- Inclusion in PubMed and all major indexing services

- Maximum visibility for your research

Submit your manuscript at www.biomedcentral.com/submit 